\title{
Cellulose Microfiber Encapsulated Probiotic: Viability, Acid and Bile Tolerance during Storage at Different Temperature
}

\author{
Usman Pato ${ }^{1 *}$, Dewi Fortuna Ayu ${ }^{1}$, Emma Riftyan ${ }^{1}$, Fajar Restuhadi ${ }^{1}$, \\ Wasisso Tunggul Pawenang ${ }^{1}$, Royyan Firdaus ${ }^{1}$, Annisa Rahma ${ }^{1}$, Irwandi Jaswir ${ }^{2}$ \\ ${ }^{1}$ Department of Agricultural Technology, Faculty of Agriculture, Universitas Riau, Pekanbaru, Indonesia. \\ ${ }^{2}$ International Institute for Halal Research and Training, Internasional Islamic University Malaysia, 53100 Jalan Gombak, Selangor, Malaysia.
}

\begin{abstract}
This work aimed to analyze the physicochemical properties of cellulose from OPT used in the fabrication of CMF and evaluate the efficacy of the hydrogel CMF as an encapsulant for $L$. fermentum InaCC B1295 stored at room temperature and in the refrigerator. The Kjeldahl method was used to evaluate the protein content; the gravimetric method was used to determine OPT's ash, moisture, and fiber contents; the Soxhlet method was used to determine the fat content carbohydrates were computed using the difference method. The levels of holocellulose, lignin, and cellulose were also determined. Viability, acid and bile resistance of strain B1295 were evaluated at various temperatures for 35 days. The most abundant component of OPT fiber was cellulose, followed by hemicellulose and lignin. XRD examination revealed that OPT cellulose has a crystal index of $83.40 \%$. FTIR analysis was used to detect the stretching vibrations of the $-\mathrm{OH}$ group on cellulose at $3419.03 \mathrm{~cm}^{-1}$. CMF hydrogel from OPT sustained L. fermentum InaCC B1295 survival for up to 28 days at room and refrigerated temperatures. At acidic conditions and in the presence of bile, the viability of L. fermentum InaCC B1295 was excellent, with a drop in cell population of less than $0.2 \mathrm{log} \mathrm{CFU} / \mathrm{g}$ over 35 days at room and refrigerated temperatures. CMF obtained from OPT can be used as an encapsulant to maintain viability, acid resistance and bile of probiotics. There is still a need for research into the usage of CMF from OPT in combination with other encapsulants to extend the storage life of L. fermentum InaCC B1295.
\end{abstract}

Keywords:

Cellulose Microfiber;

Oil Palm Trunk;

Viability;

Acid and Bile Tolerance.

Article History:

$\begin{array}{llll}\text { Received: } & 09 & \text { September } & 2021 \\ \text { Revised: } & 11 & \text { November } & 2021 \\ \text { Accepted: } & 19 & \text { December } & 2021 \\ \text { Published: } & 01 & \text { February } & 2022\end{array}$

\section{1- Introduction}

Indonesia is the world's top palm oil producer, with 16.37 million hectares of land and 45.8 million tons of CPO production in 2020. There is a high likelihood of palm oil waste with such a vast oil palm plantation, including empty fruit bunches, oil palm trunks, oil palm fronds, and oil palm leaves. According to the analysis, only $10 \%$ of an oil palm tree is oil; $90 \%$ is biomass such as the trunk, frond, leaves, palm oil shells, and empty fruit bunches [1]. Oil palm trunk (OPT) waste is generally obtained during replanting when the oil palm plants have reached 25-30 years. Approximately about 2.76 million hectares of oil palm will be replanted in Indonesia [2]. Thus, OPT waste is abundant from replanting today and the next few years. OPT waste was usually burned in the past, but the new waste was difficult to burn, so it was usually left to accumulate in palm oil fields to decompose entirely within five years [3]. Today and in the future, OPT can be used to make various high-value products, including medium-density panels, laminated veneer wood, nanocomposites, pulp and paper [4-6]. OPT can also be used as a source of starch [7, 8] and feed for ruminants [9].

\footnotetext{
* CONTACT: usmanpato@yahoo.com
}

DOI: http://dx.doi.org/10.28991/ESJ-2022-06-01-08

(C) 2022 by the authors. Licensee ESJ, Italy. This is an open access article under the terms and conditions of the Creative Commons Attribution (CC-BY) license (https://creativecommons.org/licenses/by/4.0/). 
Recently, OPT has been used in the production of cellulose microfibers (CMF). CMF, also known as microfibrillated cellulose, is cellulose that has been processed into microfibrils ranging in diameter from 10 to $100 \mu \mathrm{m}$. CMF has a high specific surface area, strength, and stiffness and is lightweight, biodegradable, and renewable [10]. CMF can be utilized in the paper, paint and coating, automotive, electronics, composites, food and cosmetics, and medical industries due to their properties [11-13]. CMF may also be used to encapsulate probiotic and bioactive substances in food. To exert therapeutic effects, a possible probiotic strain must possess specific desirable characteristics, including viability during manufacturing, storage, and marketing, as well as acid and bile tolerance [14]. Encapsulation is designed to maintain probiotic viability at a minimum of $10^{7} \log \mathrm{CFU} / \mathrm{ml}$ as it goes through the digestive tract to perform its therapeutic function $[15,16]$. Probiotics have been shown to benefit health and wellness in various ways, including modulating the gut microbiota by inhibiting pathogenic microorganisms, generating anticarcinogenic chemicals, and modulating immunological responses [17]. The probiotic foods industry continues to grow each year, with numerous markets including functional foods and beverages, dietary supplements, and animal feed. Between 2016 and 2022, the probiotics market is expected to reach $\$ 57.4$ billion, increasing at a compound annual growth rate of $7.7 \%$ [18]. Producing foods with probiotic claims, on the other hand, is challenging due to the problems inherent in the survival and retention of probiotic cells added to foods during manufacturing, storage, distribution, and consumption [19]. Simultaneously, cell encapsulation is gaining popularity to extend the life of probiotics added to a variety of food matrices [20]. Carbohydrates such as dextrins, pectins, cellulose, chitosan, carrageenan; lipids such as wax, paraffin, mono, and diglycerides; and proteins like milk gluten, casein, gelatin, and albumin are all commonly used as encapsulant materials [21, 22]. Many fermented dairy products have been effectively encapsulated with various encapsulating materials to protect probiotic microorganisms [23]. Numerous intrinsic and extrinsic parameters, including $\mathrm{pH}$, storage temperature, hydrogen peroxide generation, oxygen, and fermentation conditions, affect probiotic survival in food items [24].

Cell encapsulation techniques are designed to preserve viable and functional cells within a semi-permeable matrix. The effectiveness of various encapsulating materials is also critical for the stability of the encapsulated bacterial particles, including 1) easy separation of cells from products, 2) increased productivity due to high cell concentrations achieved, 3) protection of cells from harsh environmental conditions, 4) the ability to use packed columns, and 5) reusability of the immobilized cells [25]. Additionally, these materials must be biocompatible and permeable to oxygen, nutrients, and potentially toxic metabolites to ensure cell survival [26]. As a result, they must manage the release through the human stomach and intestines [27]. A previous study found that CMF hydrogel from oil palm leave (OPL) was only able to maintain the viability of $L$. fermentum InaCC B 1295 for 28 days and resistance to acid and bile after storage for 35 days at room and cold temperatures [28]. Considering the potential for OPT waste which is very abundant at the time of replanting, it is necessary to test the ability of CMF from OPT to maintain viability and resistance to acid and bile during storage at room temperature and cold temperatures.

\section{2- Materials and Method}

\section{2-1-Materials}

Palm oil solid waste used to make CMF is OPTs obtained by oil palm plantations in Riau, Indonesia. Lactobacillus fermentum InaCC B1295 was obtained from the Indonesian Culture Collection (InaCC), Research Center for Biology, Indonesian Institute of Sciences (LIPI), West Java, Indonesia. 89\% polyvinyl alcohol was purchased from SigmaAldrich, Steinheim, Germany.

\section{2-2-Characterization of OPT}

The Kjeldahl method was used to evaluate the protein content; the gravimetric method was used to determine OPT's ash, moisture, and fiber contents; the Soxhlet method was used to determine the fat content carbohydrates were computed using the difference method [29]. Additionally, the levels of holocellulose, lignin, and cellulose were determined according to Jung et al. [30].

\section{2-3-Cellulose Separation}

The procedure described by Fahma et al. [11] was used to isolate cellulose. Before being exposed to any treatment, the OPT was trimmed to $0.5-1 \mathrm{~cm}$ in length. The holocellulose was extracted by bleaching the fibers for 12 hours with a $6 \%$ potassium hydroxide solution and then rinsing with deionized water until a $\mathrm{pH}$ of 7 was achieved. Following that, the extracted fibers were immersed in a $\mathrm{NaClO}_{2}$ solution for 5 hours at $\mathrm{pH} 4-5$. Lignin was removed by rinsing with deionized water. Before proceeding with further analysis, the cellulose fibers were refrigerated.

\section{2-4- FTIR Analysis}

The chemical composition and bonding of cellulose were determined using an FTIR spectrometer. A Thermo Nicolet Nexus spectrometer connected to an ATR detector was used to acquire the FTIR spectra of cellulose samples. All spectra were acquired at a resolution of $4 \mathrm{~cm}^{-1}$ using 32 scans in the spectral range 7800-350 $\mathrm{cm}^{-1}$. OMNIC 6.0 (Thermo Scientific Nicolet iS10) software was used to analyze the spectrum data. 


\section{2-5-XRD Analysis}

XRD analysis was used to identify the chemical groups and degree of crystallinity of cellulose. The XRD analysis was conducted on the X'Pert PRO PANalytical instrumentation. CuK radiation with a wavelength of 0.154 was employed in the XRD test settings. The XRD test is conducted at a voltage and current of $30 \mathrm{~mA}$ and $40 \mathrm{kV}$. The diffraction rate is between $5^{\circ}$ to $50^{\circ}$ per second, with an increased rate of $2 \theta-0.02^{\circ}$ per second. The crystallinity index (CrI) was calculated according to the following equation:

$$
\mathrm{CrI}=\frac{\mathrm{I}_{002}-\mathrm{I}_{\mathrm{am}}}{\mathrm{I}_{002}} \times 100 \%
$$

Where; $\mathrm{I}_{002}$ is a diffraction intensity of $2 \theta=23$, which indicates the crystalline region of the material. $\mathrm{I}_{\mathrm{am}}$ refers to the peak at about $2 \theta=18$, which indicates the amorphous region of the compound [31].

\section{2-6-Preparation of CMF}

CMF was prepared according to the Lestari technique [32]. First, OPT was fragmented, ranging in length from 0.5 to $1 \mathrm{~cm}$, rinsed with water, and cooked for 1 hour in boiling water $\left(100^{\circ} \mathrm{C}\right)$. They were then filtered. Following boiling, the OPT was thoroughly rinsed with water and dried for four $\mathrm{h}$ at $60^{\circ} \mathrm{C}$. The fiber was then placed in a beaker with $1000 \mathrm{cc}$ of $6 \%(\mathrm{w} / \mathrm{v}) \mathrm{KOH}$ and left to soak for 12 hours at room temperature. The fibers are then washed with water three times. Additionally, washed fibers are steeped for 5 hours in a hypochlorite solution before being filtered and rinsed with water pH 7. After drying and crushing OPT in a blender until smooth, it was filtered through a sieve with a screen no 80 . To avoid sample damage caused by milling heat, CMF was handled by milling the cellulose flour at an 8,000 rpm speed for 60 minutes with a run time of 15 seconds and a rest period of 2 minutes. The milled product was then sieved through a sieve with a screen no 100 to get CMF. The flowchart of the research is presented in Figure 1.

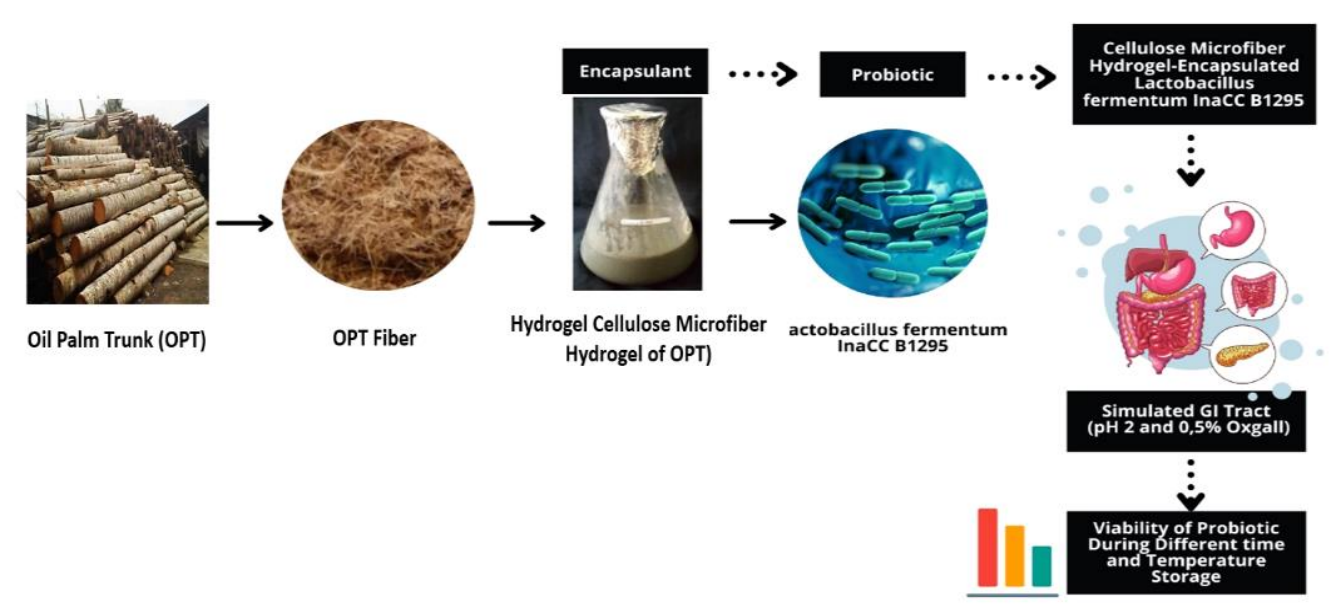

Figure 1. Flowchart of the research methodology

\section{2-7-MRSB Medium Preparation}

The MRSB medium was prepared by weighing $13.78 \mathrm{~g}$ of MRSB powder and diluting it with distilled water to a volume of $250 \mathrm{~mL}$. The fluid was divided into $5 \mathrm{ml}$ test tubes and sealed using a setup. Then place in an autoclave for 15 minutes at $121^{\circ} \mathrm{C}, 1 \mathrm{~atm}$. Finally, the MRSB medium is complete and ready for use.

\section{2-8-MRSA Medium Preparation}

MRSA medium was made by weighing $68.2 \mathrm{~g}$ of MRSA powder and adding $1000 \mathrm{~mL}$ of distilled water, stirring until dissolved. The medium was then heated and swirled until homogenous. Additionally, sterilization was performed using an autoclave at $121^{\circ} \mathrm{C}, 1 \mathrm{~atm}$ for 15 minutes. Finally, $15 \mathrm{~mL}$ sterilized Petri dishes were filled with the homogenous MRS agar solution. The medium is poured in laminar airflow. The media-containing petri dish is then sealed and allowed to harden.

\section{2-9- L. Fermentum InaCC B1295 Source and Activation}

The strain B1295 was isolated from dadih, a traditional fermented from buffalo milk in West Sumatera, Indonesia. The culture was activated by inoculating $1 \mathrm{~mL}$ into a $5 \mathrm{~mL}$ MRSB medium test tube and vortex stirring. After that, the medium was incubated at $37^{\circ} \mathrm{C}$ for 24 hours to obtain the active culture stock. Then the active culture was prepared for research. 


\section{2-10-Preparation of CFS}

Active culture of strain B1295 was inoculated into a sterile MRSB medium and incubated for 24 hours at $37^{\circ} \mathrm{C}$. This mixture was centrifuged at $4500 \mathrm{rpm}$ for 15 minutes following incubation to separate cells from the supernatant. After removing the supernatant, the cells were washed twice with sterile distilled water to achieve clean cells. After adding phosphate buffer at a 1:1 (w/v) ratio, the CFS was deposited in clean containers and kept at $4^{\circ} \mathrm{C}$.

\section{2-11-CMF Hydrogel Preparation}

The first stage was to prepare $8 \%(\mathrm{w} / \mathrm{v})$ polyvinyl alcohol. PVA was weighed at $96 \mathrm{~g}$, then combined with $1104 \mathrm{~mL}$ distilled water and heated to $100^{\circ} \mathrm{C}$ until dissolved using a hot magnetic stirrer. Allow sufficient time for the PVA solution to cool to room temperature. $250 \mathrm{~g}$ PVA $8 \%$ was combined with $250 \mathrm{~mL} \mathrm{CMF}$ and heated at $60^{\circ} \mathrm{C}$ until the CMF dissolved entirely, resulting in a CMF hydrogel (CMFH). The $\mathrm{pH}$ and viscosity of the $\mathrm{CMFH}$ were then determined using a pH meter and viscometer. The hydrogel was then autoclaved at $121^{\circ} \mathrm{C}$ for 15 minutes. Sterile CMFH was cooled to room temperature and ready to be used as a LAB encapsulant [33].

\section{2-12-Encapsulation of L. Fermentum InaCC B1295}

The process for encapsulating L. fermentum InaCC B1295 was somewhat modified from Yasim-Anuar et al. [34]. 40 $\mathrm{mL}$ of sterile CNF hydrogel was added to $40 \mathrm{~mL}$ of cell biomass and swirled until thoroughly mixed using a stirring rod. Following that, the probiotic features of the encapsulated LAB were evaluated.

\section{2-13-Treatment at Various Temperatures and Storage Times}

Two $\mathrm{ml}$ of each encapsulated probiotic was placed in a $5 \mathrm{~mL}$ cryovial and then kept at room and cold temperatures for 35 days. The encapsulated probiotic was then examined for viability and resistance to acid and bile at days $0,7,14$, 21,28 , and 35 [35][36].

\section{2-14-Data Analysis}

Data on physico-chemical properties of OPT, fiber, and CMF were analyzed descriptively, while data on resistance to acid and bile and viability were analyzed statistically using ANOVA and DMRT with SPSS version 26 [37].

\section{3- Results and Discussion}

\section{3-1- Physicochemical Characteristics of OPT and Cellulose}

Whole OPT flour was analyzed to determine the moisture content and chemical constituents, and the results are presented in Table 1. The main content of OPL was crude fiber and carbohydrates, 42.55 and 37.39\%, respectively. The primary carbohydrate in OPT was starch, made up of $71.24 \%$ amylopectin and $28.76 \%$ amylose. According to the amylograph investigation, the oil palm starch's final viscosity was more remarkable than commercial starch [38].

Table 1. The moisture content and chemical composition of whole OPT flour

\begin{tabular}{cc}
\hline Chemical compounds & Amount (\%) \\
\hline Water & 10.23 \\
Ash & 6.08 \\
Fat & 0.78 \\
Protein & 2.99 \\
Crude fiber & 42.55 \\
Carbohydrate & 37.39 \\
\hline
\end{tabular}

OPL also contained small amounts of ash, protein, fat, and water. Winarni et al. [30] similarly found that the moisture and ash content of the OPL was nearly identical to the moisture and ash content of this study, which was 10.5 and $6.73 \%$, respectively. Compared with the composition between OPT and OPL, protein and fat levels were higher in OPL than in OPT. On the other hand, the levels of carbohydrates and ash were higher in OPT than in OPL. The crude fiber content in both samples was relatively the same in OPT and OPL [28]. It is essential to determine the fiber content of OPT to prepare CMF, which is provided in Table 2.

Table 2. Cellulose, hemicellulose, and lignin contents from OPT

\begin{tabular}{cc}
\hline Components & Amount (\%) \\
\hline Cellulose & 52.0 \\
Holocellulose & 25.2 \\
Lignin & 22.8 \\
\hline
\end{tabular}


OPT fiber was mainly composed of cellulose, and the rest was holocellulose and lignin in almost equal amounts. The OPT fiber content in this study was higher than the previous findings of 40.95-41.72\% [40]. Because of the high cellulose content, the plant cell walls and fibers are more robust and more stable. In contrast, OPL fiber is mainly lignin, followed by cellulose and holocellulose [28]. Lignin is a substance found in the cell walls and between cells of vascular plants. Vascular and parenchymal bundles contain lignin as much as 15.7 and 20.0 of the whole chip of OPT, respectively [41]. Deli [42] similarly recorded a lignin content of $19.20 \%$ in OPT Lignin is primarily a supporting structure that contributes to tall plants' secondary thickening. This fact results in a more significant concentration of lignin content of the stem than in other regions of the plant. The presence of lignin in the stems aids the plant in remaining rigid and solid and preventing collapse [43]. The crystallinity of the cellulose extracted from OPT was then determined using X-Ray Diffraction (Figure 2).

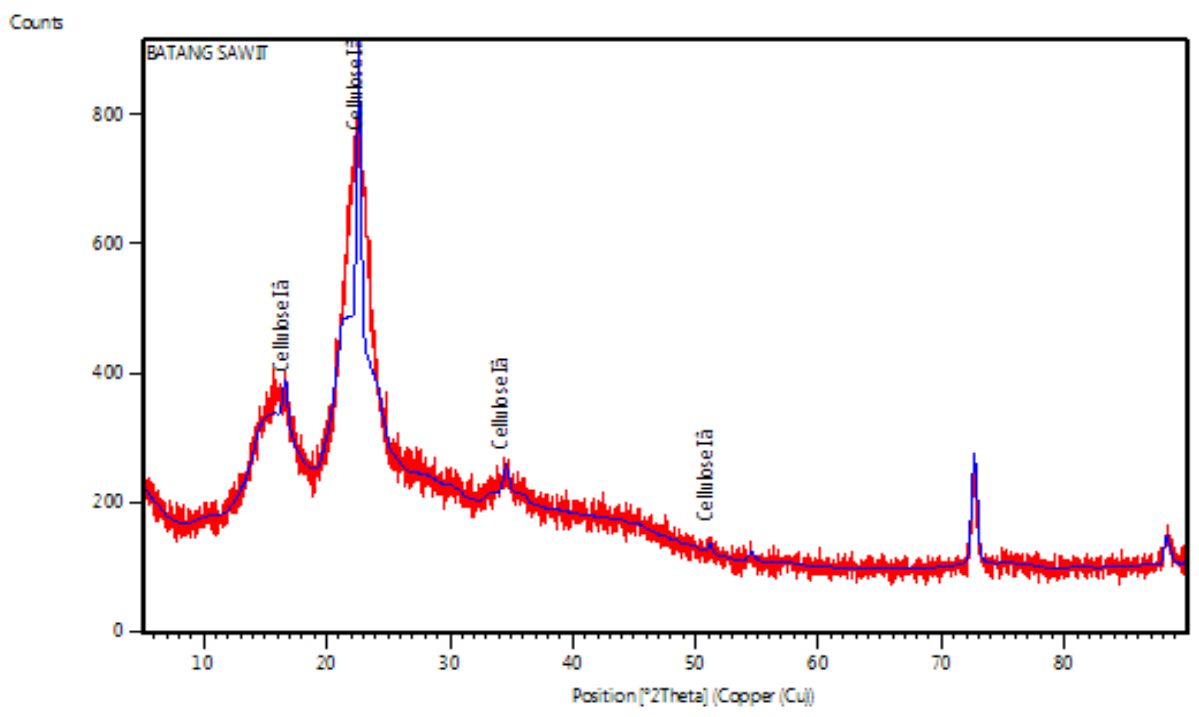

Figure 2. XRD diffractogram of cellulose of OPT

Five diffraction peaks were seen in the XRD pattern of OPT celluloses at $2 \theta=16,22,34,51$, and $88^{\circ}$. This result is different from our previous finding, which found seven diffraction peaks at $2 \theta=15,17,22,34,42,43$ and $72^{\circ}$ in cellulose from oil palm leaves. The XRD diffractogram of CNF from OPM revealed a strong reflection at $2 \theta=21$ to $22^{\circ}$ as well as small peaks at $2 \theta=18$ to $19^{\circ}$ and 35 to $42^{\circ}$ [34]. In this figure, potassium hydroxide was also detected at peaks at $2 \theta$ $=54^{\circ}$ and $22^{\circ}$. This compound was used to separate cellulose from lignin and hemicellulose. The presence of potassium hydroxide may be due to the incomplete washing process with distilled water or because this compound bound firmly to the components in the fiber so that it was not easily separated from the cellulose during washing. Additionally, XRD analysis was used to assess the crystallinity level of the OPT cellulose (Table 3).

Table 3. Crystal index of cellulose from OPT

\begin{tabular}{cc}
\hline Parameters & Value \\
\hline $\mathrm{I}_{002}$ & 323.53 \\
$\mathrm{I}_{\mathrm{AM}}$ & 53.77 \\
Crystal index $(\%)$ & 83.38 \\
\hline
\end{tabular}

The degree of crystallinity of the OPT was relatively high in this investigation, at $83.40 \%$. This value is significantly greater than the previously reported crystallinity of $64.66 \%$ in OPT [40]. OPT has a higher crystallinity index when compared to OPL, which is only $10.1 \%$ [28]. The stiffness of the fiber increases as the degree of crystallinity increases [44]. The crystalline structure of cellulose is crucial in determining the material's elasticity, stiffness, thermal stability, and absorption properties [45].

FTIR spectroscopy is an analytical technique used to determine the functional groups in polymer materials and characterize them. The residual spectra of energy absorption by organic molecules in infrared light can be determined and recorded. The term "infrared" refers to a wavelength range of 1-500 $\mathrm{cm}^{-1}$. Figure 3 illustrates the outcome of an FTIR study of cellulose from OPT. 


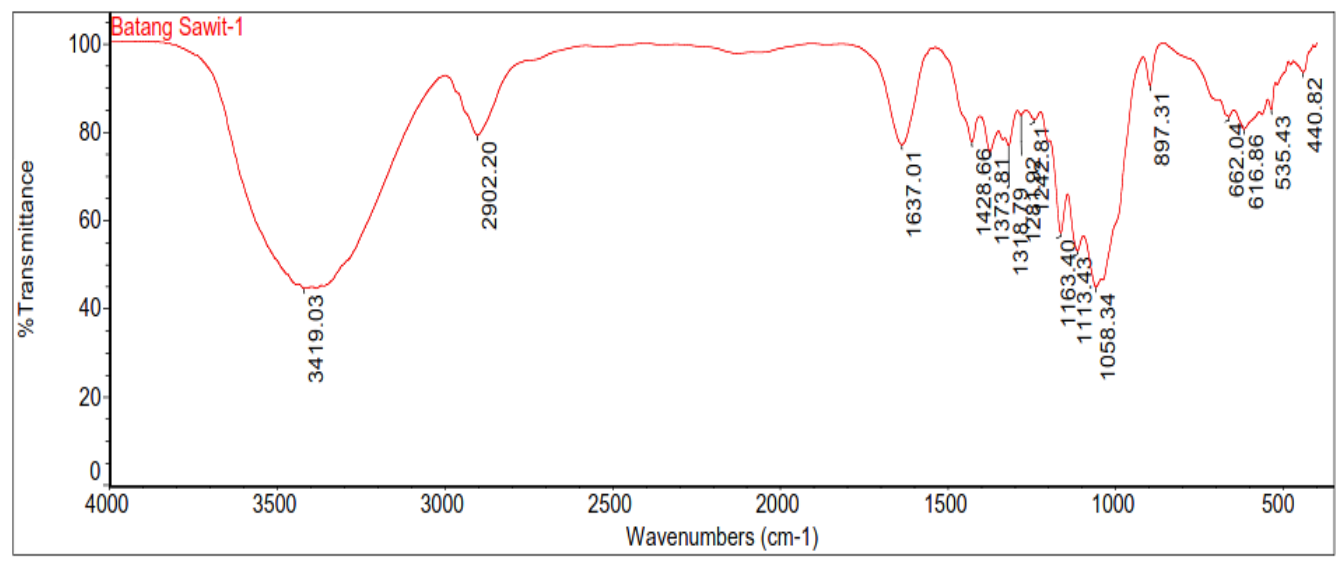

Figure 3. FTIR spectra of cellulose from OPT

The dominant absorption peak in OPT was $3419.03 \mathrm{~cm}^{-1}$, which corresponded to the stretching vibrations of the $-\mathrm{OH}$ group on cellulose. The identical observation was made in the cellulose of an EOPFB [11]. CH stretching in OPT had the next highest absorption peak at $2902.20 \mathrm{~cm}^{-1}$. The tiny peaks in OPT-cellulose with diameters ranging from 1637.01 to $1282.41 \mathrm{~cm}^{-1}$ were carbonyl groups in holocellulose or lignin. The peak at $1163.40-1058.34 \mathrm{~cm}^{-1}$ is assumed to represent a C-C aromatic loop of linked lignin or a $\mathrm{C}-\mathrm{H}$ and $\mathrm{C}-\mathrm{O}$ ester bond stretching vibration generated by partial acetylation of the hydroxyl group in lignin or carbohydrate residues [46]. The FTIR spectra of OPT revealed similarities to that of OPL [28].

\section{3-2- Viability of Strain B1295}

One of the conditions for probiotics to execute their therapeutic effect when taken is their viability. The Anova revealed that storage duration significantly influenced probiotic viability $(\mathrm{P}<0.05)$. However, storage temperature was not significantly affected on probiotic survival $(\mathrm{P}<0.05)$, as shown in Table 4 . From days 7 to 35 , LAB decreased at both storage temperatures encapsulated in OPT's CMFH. At room temperature, the probiotic concentration declined from $10.15 \log \mathrm{CFU} / \mathrm{g}$ to $5.06 \log \mathrm{CFU} / \mathrm{g}$ and from $10.20 \mathrm{log} \mathrm{CFU} / \mathrm{g}$ to $5.46 \log \mathrm{CFU} / \mathrm{g}$ when refrigerated. The LAB decrease was slightly more at room temperature than at refrigerated temperature, but on day 35, the number of LAB was below $10^{7} \mathrm{CFU} / \mathrm{g}$ at different temperatures as a probiotic requirement. This conclusion is attributable to the fact that as storage time increases, the CMFH layer covering the probiotic cells loses its stability due to the CMFH's increased humidity. Increased humidity reduces the tensile strength and flexibility of $\mathrm{CMFH}$, allowing the gel link to expand and bacteria to readily escape the coating, exposing them to direct temperature, causing cell damage, and inhibiting bacterial development. This remark aligns with Sianturi [47], who indicated that PVA-containing hydrogels' toughness depends on humidity. More water is absorbed when humidity rises, lowering tensile flexibility and strength. The current findings corroborated a prior observation that the encapsulant matrix's durability decreased as the storage period increased [48]. At both room and cold temperatures, the CMFH from OPT maintained probiotic viability for $28 \mathrm{~d}$. The study discovered that probiotics encapsulated in OPT and OPF cellulose nanofiber hydrogel (CNFH) were alive for 5 and 21 days, respectively [33]. We previously discovered that strain B1295 also had a survival time of 28 days in CMFH from OPL [28]. These results demonstrate that when stored under the same conditions, different types of palm oil solid waste have no effect on the survival of LAB but are strongly reliant on the type of LAB encapsulated. LAB encapsulated in a mixture of some compounds maintained survivability of greater than $10^{7} \mathrm{CFU} / \mathrm{g}$ for 180 days at low temperatures and $120 \mathrm{~d}$ at room temperature [49].

Table 4. Viability of strain B1295 microencapsulated with CMFH from OPT at different temperatures for 35 days storage

\begin{tabular}{ccc}
\hline \multirow{2}{*}{ Storage time (d) } & \multicolumn{2}{c}{ Number of LAB (log CFU/g) } \\
\cline { 2 - 3 } & Room temperature & Refrigerated temperature \\
\hline 0 & ${ }^{\mathrm{x}} 10.15^{\mathrm{d}}$ & ${ }^{\mathrm{y}} 10.20^{\mathrm{d}}$ \\
7 & ${ }^{\mathrm{x}} 7.39^{\mathrm{b}}$ & ${ }^{\mathrm{y}} 7.84^{\mathrm{bc}}$ \\
14 & ${ }^{\mathrm{x}} 7.55^{\mathrm{b}}$ & ${ }^{\mathrm{y}} 7.67^{\mathrm{b}}$ \\
21 & ${ }^{\mathrm{x}} 7.82^{\mathrm{c}}$ & ${ }^{\mathrm{y}} 7.99^{\mathrm{c}}$ \\
28 & ${ }^{\mathrm{x}} 7.43^{\mathrm{b}}$ & ${ }^{\mathrm{y}} 7.93^{\mathrm{c}}$ \\
35 & ${ }^{\mathrm{x}} 5.06^{\mathrm{a}}$ & ${ }^{\mathrm{y}} 5.46^{\mathrm{a}}$ \\
\hline
\end{tabular}

a,b,c,d, Different letters within a column indicate significant differences at $\mathrm{P}<0.05$

${ }^{x, y}$ Different letters within a column indicate significant differences at $\mathrm{P}<0.05$ 
In comparison to free cells, the combination of whey protein isolate and fructooligosaccharide microcapsules considerably boosted bacteria stability in the product over 30 days at $4{ }^{\circ} \mathrm{C}$, averaging $8.57 \log \mathrm{CFU} / \mathrm{g}$ for L. acidophilus and $7.61 \log$ CFU/g for L. casei [50]. Additionally, this study discovered that strain B1295 had longer viability at cold temperatures than at room temperature. These results are consistent with those obtained previously in L. acidophilus encapsulated with maltodextrin and gum arabic [51].

\section{3-3- Acid resistance of Strain B1295}

Probiotics consumed must be acid-resistant in the stomach to reach the colon and perform their therapeutic effect [52]. Table 5 summarizes the acid resistance of strain B1295 encapsulated in CMFH and stored at different conditions before being treated for $5 \mathrm{~h}$ at $\mathrm{pH}$ 2. For 5 hours, strain B1295 was treated at $\mathrm{pH} 2$ to adapt to the circumstances and food retention duration in the human stomach. L. fermentum InaCC B1295 was stored for 35 days in the room, and cold temperatures showed viability above $10^{9} \mathrm{CFU} / \mathrm{g}$ after being treated under acidic conditions. This finding indicates that even if strain B1295 is consumed, it will still have more than the $7.0 \mathrm{log}$ CFU/g required to perform its therapeutic function. Since the CMFH from OPT was still coating the probiotic cells at low $\mathrm{pH}$ levels, many probiotics were still alive. The viability of strain B1295 was marginally more significant when held at cold temperatures than when stored at room temperature. This finding is most likely related to the cold gel state, which directly affects the viability of the encapsulated cells. Compared to CMFH OPT and CMFH OPL, the amount of probiotic cells was comparable, ranging between 8.94 and $9.89 \log$ CFU/g after 0-35 days of storage at room temperature and cold temperature [28].

Table 5. Number of strain B1295 microencapsulated with CMFH from OPT at different temperatures for 35 days storage and treated at $\mathrm{pH} 2$

\begin{tabular}{ccc}
\hline \multirow{2}{*}{ Storage time (d) } & \multicolumn{2}{c}{ Number of LAB $(\log$ CFU/g) } \\
\cline { 2 - 3 } & Room temperature & Refrigerated temperature \\
\hline 0 & ${ }^{\mathrm{x}} 9,83^{\mathrm{d}}$ & ${ }^{\mathrm{y}} 9,89^{\mathrm{d}}$ \\
7 & ${ }^{\mathrm{x}} 9,37^{\mathrm{c}}$ & ${ }^{\mathrm{y}} 9,44^{\mathrm{c}}$ \\
14 & ${ }^{\mathrm{x}} 9,13^{\mathrm{b}}$ & ${ }^{\mathrm{y}} 9,20^{\mathrm{b}}$ \\
21 & ${ }^{\mathrm{x}} 9,09^{\mathrm{a}}$ & ${ }^{\mathrm{y}} 9,19^{\mathrm{b}}$ \\
28 & ${ }^{\mathrm{x}} 9,07^{\mathrm{a}}$ & ${ }^{\mathrm{y}} 9,09^{\mathrm{ab}}$ \\
35 & ${ }^{\mathrm{x}} 9,05^{\mathrm{a}}$ & ${ }^{\mathrm{y}} 9,03^{\mathrm{a}}$ \\
\hline${ }^{\mathrm{a}, \mathrm{b}, \mathrm{b}, \mathrm{d}, \mathrm{d}}$ Different letters within a column indicate significant differences at $\mathrm{P}<0.05$ & \\
${ }_{\mathrm{x}, \mathrm{y}}$ Different letters within a column indicate significant differences at $\mathrm{P}<0.05$ &
\end{tabular}

Additionally, the number of cells decreased insignificantly at both ambient and refrigerator temperatures (Table 6).

Table 6. The amount of reduction in strain B1295 microencapsulated with CMFH from OPT at different temperatures for 35 days storage and treated with $\mathrm{pH} 2$

\begin{tabular}{ccc}
\hline \multirow{2}{*}{ Storage time (d) } & \multicolumn{2}{c}{ Number of LAB (log CFU/g) } \\
\cline { 2 - 3 } & Room temperature & Refrigerated temperature \\
\hline 0 & ${ }^{\mathrm{x}} 0,08^{\mathrm{a}}$ & ${ }^{\mathrm{x}} 0,02^{\mathrm{a}}$ \\
7 & ${ }^{\mathrm{x}} 0,02^{\mathrm{a}}$ & ${ }^{\mathrm{x}} 0,03^{\mathrm{a}}$ \\
14 & ${ }^{\mathrm{x}} 0,09^{\mathrm{a}}$ & ${ }^{\mathrm{x}} 0,08^{\mathrm{a}}$ \\
21 & ${ }^{\mathrm{x}} 0,09^{\mathrm{a}}$ & ${ }^{\mathrm{x}} 0,18^{\mathrm{a}}$ \\
28 & ${ }^{\mathrm{x}} 0,10^{\mathrm{a}}$ & ${ }^{\mathrm{x}} 0,17^{\mathrm{a}}$ \\
35 & ${ }^{\mathrm{x}} 0,07^{\mathrm{a}}$ & ${ }^{\mathrm{x}} 0,11^{\mathrm{a}}$ \\
\hline
\end{tabular}

${ }^{a}$ Different letters within a column indicate significant differences at $\mathrm{P}<0.05$

${ }^{\mathrm{x}}$ Different letters within a column indicate significant differences at $\mathrm{P}<0.05$

The decrease in the probiotic count was slight, demonstrating that the CMFH from OPT can keep this LAB alive in extremely acidic circumstances. The reduction in Strain B1295 was also not statistically different at all temperatures and storage conditions. This finding was most likely due to the CMFH from OPT wrapping the probiotic cells for $5 \mathrm{~h}$ at $37^{\circ} \mathrm{C}$ while they were treated at $\mathrm{pH} 2$. Because strain B1295 cells did not come into direct contact with hydrogen chloride, the amount of strain B1295 was reduced by less than $0.20 \mathrm{log}$ CFU/g over a range of storage periods and temperatures. The hydrogel protects the cells from numerous environmental conditions unfavourable to LAB cells, such as extremely low $\mathrm{pH}$ [24]. Under the same storage conditions, the amount of strain B1295 encapsulated with CMFH from OPT decreased roughly identically to the amount of CMFH from OPL, between 0.03 and 0.47 loc cycle [28]. The present 
results revealed that strain B1295 had a somewhat lower cell number than other researchers' findings. For 8 weeks, the cell count of encapsulated L. acidophilus and Bifidobacterium spp reduced by around $0.5 \log$ CFU/g, while unattached cells fell by around $1 \log \mathrm{CFU} / \mathrm{g}$ [53]. Other studies discovered that after 3 hours of incubation at $\mathrm{pH} 2$, co-encapsulated probiotics' viability fell by $1.62 \mathrm{log} \mathrm{CFU} / \mathrm{g}$, encapsulated probiotics' viability declined by $3.9 \mathrm{log}$ CFU/g, and free probiotics' viability decreased by $4.5 \mathrm{log}$ CFU/g [54]. Encapsulated bacteria reduced $3 \log \mathrm{CFU} / \mathrm{g}$ throughout the simulated gastrointestinal test, while free cells decreased $7 \mathrm{log}$ CFU/g [55]. L. rhamnosus encapsulated in chitosan microbeads was only able to maintain a $0.94 \log \mathrm{CFU} / \mathrm{g}$ drop in cell counts when exposed to acidic conditions for $40-$ 120 minutes [56].

\section{3-4- Bile resistance of Strain B1295}

Because LAB must travel through the upper part of the small intestine to perform their therapeutic activity in the digestive system, resistance to bile is one of the probiotic selection criteria [57]. Table 7 shows the bile resistance of strain B1295 stored at various storage durations and temperatures.

Table 7. Number of strain B1295 microencapsulated with CMFH from OPT at different temperatures for 35 days storage and treated with bile

\begin{tabular}{ccc}
\hline \multirow{2}{*}{ Storage time $(\mathbf{d})$} & \multicolumn{2}{c}{ Number of LAB (log CFU/g) } \\
\cline { 2 - 3 } & \multicolumn{1}{c}{ Room temperature } & Refrigerated temperature \\
\hline 0 & ${ }^{\mathrm{x}} 9,88^{\mathrm{b}}$ & ${ }^{\mathrm{x}} 9,93^{\mathrm{c}}$ \\
7 & ${ }^{\mathrm{x}} 9,57^{\mathrm{ab}}$ & ${ }^{\mathrm{x}} 9,71^{\mathrm{b}}$ \\
14 & ${ }^{\mathrm{x}} 9,64^{\mathrm{b}}$ & ${ }^{\mathrm{x}} 9,67^{\mathrm{b}}$ \\
21 & ${ }^{\mathrm{x}} 9,70^{\mathrm{b}}$ & ${ }^{\mathrm{x}} 9,68^{\mathrm{b}}$ \\
28 & ${ }^{\mathrm{x}} 9,32^{\mathrm{a}}$ & ${ }^{\mathrm{x}} 9,37^{\mathrm{a}}$ \\
35 & ${ }^{\mathrm{x}} 9,32^{\mathrm{a}}$ & ${ }^{\mathrm{x}} 9,40^{\mathrm{a}}$ \\
\hline $\mathrm{a}, \mathrm{b}, \mathrm{c}$ Different letters within a column indicate significant differences at $\mathrm{P}<0.05$ & \\
${ }^{\mathrm{x},}$ Different letters within a column indicate significant differences at $\mathrm{P}<0.05$ &
\end{tabular}

The results showed that this $\mathrm{LAB}$ was resistant to bile during storage at room temperature and refrigerated for $35 \mathrm{~d}$, with more than $9.0 \log \mathrm{CFU} / \mathrm{g}$. This amount has exceeded the minimum of $7.0 \log \mathrm{CFU} / \mathrm{mL}$ required for probiotics to perform therapeutic actions in the gastrointestinal tract. After $5 \mathrm{~h}$ of bile treatment on probiotic cells, the CMF hydrogel from OPT covered the LAB cells, resulting in many LAB treated with low pH. L. acidophilus and Bifidobacterium encapsulated in a mixture of sodium caseinate, D-glucose, mannitol, and fructooligosaccharide displayed a high level of bile resistance, as determined by the number of cells, which, at ambient temperature, varied between 8.3 and 9.2 log CFU/g [58]. The number of encapsulated strain D6SM3 cells treated with simulated gastric $\mathrm{HCl}$ was significantly more significant than the number of unencapsulated cells [59]. During the storage time at $4{ }^{\circ} \mathrm{C}$, the survivability of the free and encapsulated LAB decreased gradually. Their viability, on the other hand, plummeted at ambient temperature.

The high bile tolerance was demonstrated by lowering the minimal count of Strain B1295 by $0.10-0.72 \mathrm{log}$ CFU/g over a range of storage conditions (Table 8).

Table 8. The amount of reduction in strain B1295 microencapsulated with CMFH from OPT at different temperatures for 35 days storage and treated with bile

\begin{tabular}{ccc}
\hline \multirow{2}{*}{ Storage time (d) } & \multicolumn{2}{c}{ Number of LAB $(\log$ CFU/g) } \\
\cline { 2 - 3 } & Room temperature & Refrigerated temperature \\
\hline 0 & ${ }^{\mathrm{x}} 0,13^{\mathrm{a}}$ & ${ }^{\mathrm{x}} 0,10^{\mathrm{a}}$ \\
7 & ${ }^{\mathrm{x}} 0,12^{\mathrm{a}}$ & ${ }^{\mathrm{x}} 0,30^{\mathrm{ab}}$ \\
14 & ${ }^{\mathrm{x}} 0,11^{\mathrm{a}}$ & ${ }^{\mathrm{x}} 0,12^{\mathrm{a}}$ \\
21 & ${ }^{\mathrm{x}} 0,10^{\mathrm{a}}$ & ${ }^{\mathrm{x}} 0,14^{\mathrm{a}}$ \\
28 & ${ }^{\mathrm{x}} 0,72^{\mathrm{c}}$ & ${ }^{\mathrm{x}} 0,63^{\mathrm{b}}$ \\
35 & ${ }^{\mathrm{x}} 0,43^{\mathrm{b}}$ & ${ }^{\mathrm{x}} 0,49^{\mathrm{a}}$ \\
\hline
\end{tabular}

\footnotetext{
a,b,c Different letters within a column indicate significant differences at $\mathrm{P}<0.05$

${ }^{\mathrm{x},}$ Different letters within a column indicate significant differences at $\mathrm{P}<0.05$
}

The survivability of strain B1295 against bile was relatively high, evidenced by a slight drop in cell count $(<1$ log cycle). The number of cells encapsulated with CMFH from OPT was not significantly different between room temperature and cold temperature treatment. At the same storage circumstances, similar results were obtained using strain B1295 encapsulated in CMFH from OPL [28]. This finding demonstrates that CMFH from OPT was effective in 
protecting this probiotic in bile. CMFH from OPT, which covers the probiotic cells, so they do not directly touch the bile, could be the protective mechanism. In favourable circumstances, sodium alginate creates hydrogels with divalent cations through a similar method. The hydrogel protects the cells from various less-than-ideal environmental conditions, such as those found in bile, delivered into the small intestine's upper section to emulsify fat [24]. According to our findings, strain B1295 had a modest decline in cell counts compared to other researchers' findings. When Lactobacillus were exposed to oxgall, their viability decreased by $6.51 \mathrm{log}$ cycles in loose cells but only by 3.36 log cycles in encapsulated cells [60]. After $3 \mathrm{~h}$ exposure to $1 \%$ bile salt, the encapsulated strain 1463 decreased by just 1.4 log cycles. Free cells were decreased by 3.7-4.7 log cycles under the same circumstances. The number of free probiotic cells was reduced by 4.75 - $4.84 \log$ cycles. However, the encapsulated LA 1338 strain was reduced by just 2.2 log cycles [54]. The survival of L. gasseri SBT0274 free cells was constant at $4^{\circ} \mathrm{C}$ for 7 days before declining dramatically after that. After exposure to bile salt, the number of free cells in L. gasseri SBT0270 constantly reduced throughout $28 \mathrm{~d}$ at $4^{\circ} \mathrm{C}$ [61]. The survival rate of L. acidophilus encapsulated in calcium-alginate-soy protein isolate-based hydrogel beads remained stable after 6 hours of incubation in bile 0.5 and $1 \%$ [62].

\section{4- Conclusion}

In this study, carbohydrates, particularly fiber, were the primary component of OPT, with ash, protein, and fat forming minor components. The most abundant component of OPT fiber was cellulose, followed by holocellulose and lignin. XRD examination revealed that OPT cellulose has a crystal index of $83.40 \%$. The stretching vibrations of the $-\mathrm{OH}$ group on cellulose were detected at $3419.03 \mathrm{~cm}^{-1}$, which corresponded to the significant absorption peak in OPT OPT's CMF hydrogel-protected strain B1295 life for up to 28 days at cold and room conditions. At acidic conditions and in the presence of bile, the viability of L. fermentum InaCC B1295 was excellent, with a drop in cell population of less than $0.2 \log \mathrm{CFU} / \mathrm{g}$ over 35 days at room and cold temperatures. OPT produced during oil palm replanting can be employed as raw materials in the production of CMF, which can be used as a probiotic encapsulant. Additional research on the use of CMF from OPT combined with other encapsulants to prolong the storage life of L. fermentum InaCC B1295 is needed.

\section{5- Declarations}

\section{5-1-Author Contributions}

Conceptualization, U.P. and D.F.A.; methodology, U.P. and E.R.; software, F.R; validation, U.P., E.R. and I.J.; formal analysis, W.T.P. and R.F.; investigation, R.F., and A.R.; resources, U.P.; data curation, D.F.A.; writing-original draft preparation, U.P. and E.R.; writing - review and editing, I.J.; visualization, A.R.; supervision, U.P.; project administration, A.R.; funding acquisition, U.P. All authors have read and agreed to the published version of the manuscript.

\section{5-2-Data Availability Statement}

The data presented in this study are available in article.

\section{5-3- Funding}

This research was funded by Universitas Riau, Ministry of Education, Culture, Research, and Technology of the Republic of Indonesia with Contract Number: 852/UN.19.5.1.3/PT.01.03/2020.

\section{5-4-Acknowledgements}

We acknowledged the Ministry of Education, Culture, Research, and Technology of the Republic of Indonesia for its support of this research.

\section{5-5- Conflicts of Interest}

The authors declare that there is no conflict of interests regarding the publication of this manuscript. In addition, the ethical issues, including plagiarism, informed consent, misconduct, data fabrication and/or falsification, double publication and/or submission, and redundancies have been completely observed by the authors.

\section{6- References}

[1] Abdullah, N., \& Sulaim, F. (2013). The Oil Palm Wastes in Malaysia. Biomass Now - Sustainable Growth and Use. doi:10.5772/55302.

[2] Anonymous. Indonesian Palm Oil Data and Facts: Areas, Distribution and Challenges Webinars; 2020; Ngopini Palm \#2 Indonesian Palm Oil Show.

[3] Rosli, F., Ghazali, C. M. R., Al Bakri Abdullah, M. M., \& Hussin, K. (2016). A Review: Characteristics of Oil Palm Trunk (OPT) and quality improvement of palm trunk plywood by resin impregnation. BioResources, 11(2), 5565-5580. doi:10.15376/BIORES.11.2.5565-5580. 
[4] Abdul Khalil, H. P. S., Nurul Fazita, M. R., Bhat, A. H., Jawaid, M., \& Nik Fuad, N. A. (2010). Development and material properties of new hybrid plywood from oil palm biomass. Materials and Design, 31(1), 417-424. doi:10.1016/j.matdes.2009.05.040.

[5] Dungani, R., Jawaid, M., Khalil, H. A., Jasni, J., Aprilia, S., Hakeem, K. R., ... \& Islam, M. N. (2013). A review on quality enhancement of oil palm trunk waste by resin impregnation: Future materials. BioResources, 8(2), 3136-3156.

[6] Belgacem, C., Serra-Parareda, F., Tarrés, Q., Mutjé, P., Delgado-Aguilar, M., \& Boufi, S. (2021). The integral utilization of date palm waste to produce plastic composites. Polymers, 13(14), 2335. doi:10.3390/polym13142335.

[7] Akmar, P. F., \& Kennedy, J. F. (2001). The potential of oil and sago palm trunk wastes as carbohydrate resources. Wood Science and Technology, 35(5), 467-473. doi:10.1007/s002260100107.

[8] Cahyaningtyas, A. A., Ermawati, R., Supeni, G., Firda, A., Masruchin, N., Kusumaningrum, W. B., Pramasari, D. A., Darmawan, T., Wibowo, E. S., Triwibowo, D., Sukma, S., Gatot, J., Kav, S., Selatan, J., Khusus, D., \& Jakarta, I. (2019). Modification and Characterization of Oil Palm Trunks Starch by Hydrolysis as Bioplastic Raw Material. Jurnal Kimia Dan Kemasan, 41(1), 3744.

[9] Marlida, Y., Arnim, \& Roza, E. (2016). The effect treated of oil palm trunk by ligninase thermostable to improvement fiber quality as energy sources by ruminant. International Journal of ChemTech Research, 9(9), 429-436.

[10] Utara, S. Morphology of microfibrillated cellulose from primary sludge. Jurnal Ilmu Teknologi Kayu Tropis, $177-183$.

[11] Fahma, F., Iwamoto, S., Hori, N., Iwata, T., \& Takemura, A. (2010). Isolation, preparation, and characterization of nanofibers from oil palm empty-fruit-bunch (OPEFB). Cellulose, 17(5), 977-985. doi:10.1007/s10570-010-9436-4.

[12] Chinga-Carrasco, G. (2011). Cellulose fibres, nanofibrils and microfibrils: The morphological sequence of MFC components from a plant physiology and fibre technology point of view. Nanoscale Research Letters, 6(1), 1-7. doi:10.1186/1556-276X-6417.

[13] Lavoine, N., Desloges, I., Dufresne, A., \& Bras, J. (2012). Microfibrillated cellulose - Its barrier properties and applications in cellulosic materials: A review. Carbohydrate Polymers, 90(2), 735-764. doi:10.1016/j.carbpol.2012.05.026.

[14] Kechagia, M., Basoulis, D., Konstantopoulou, S., Dimitriadi, D., Gyftopoulou, K., Skarmoutsou, N., \& Fakiri, E. M. (2013). Health Benefits of Probiotics: A Review. ISRN Nutrition, 2013, 1-7. doi:10.5402/2013/481651.

[15] Abbasiliasi, S., Tan, J. S., Tengku Ibrahim, T. A., Bashokouh, F., Ramakrishnan, N. R., Mustafa, S., \& Ariff, A. B. (2017). Fermentation factors influencing the production of bacteriocins by lactic acid bacteria: A review. RSC Advances, 7(47), 2939529420. doi:10.1039/c6ra24579j.

[16] Sarvari, F., Mortazavian, A. M., \& Fazeli, M. R. (2014). Biochemical characteristics and viability of probiotic and yogurt bacteria in yogurt during the fermentation and refrigerated storage. Applied Food Biotechnology, 1(1), 55-61. doi:10.22037/afb.v1i1.7125.

[17] Hu, S., Wang, L., \& Jiang, Z. (2017). Dietary Additive Probiotics Modulation of the Intestinal Microbiota. Protein \& Peptide Letters, 24(5), 382-387. doi:10.2174/0929866524666170223143615.

[18] Hegazi, A. G. (2019). 2020 Market Analysis for Microbiome, Probiotics \& Gut Nutrition. 2nd International Conference on Microbiome, Probiotics \& Gut Nutrition, 3(1), 2020.

[19] Min, M., Bunt, C. R., Mason, S. L., \& Hussain, M. A. (2019). Non-dairy probiotic food products: An emerging group of functional foods. Critical Reviews in Food Science and Nutrition, 59(16), 2626-2641. doi:10.1080/10408398.2018.1462760.

[20] Rodrigues, F. J., Cedran, M. F., Bicas, J. L., \& Sato, H. H. (2020). Encapsulated probiotic cells: Relevant techniques, natural sources as encapsulating materials and food applications - A narrative review. Food Research International, 137, 109682. doi:10.1016/j.foodres.2020.109682.

[21] Anjum Ayoub, Monika Sood, Jagmohan Singh, Julie D Bandral, N. G. and A. B. (2019). Microencapsulation and its applications in food industry. Journal of Pharmacognosy and Phytochemistry, 8(3), 32-37. https://dergipark.org.tr/tr/pub/pajes/218308

[22] de la Cruz Pech-Canul, A., Ortega, D., García-Triana, A., González-Silva, N., \& Solis-Oviedo, R. L. (2020). A brief review of edible coating materials for the microencapsulation of probiotics. Coatings, 10(3), 1-34. doi:10.3390/coatings10030197.

[23] Abghari, A., Sheikh-Zeinoddin, M., \& Soleimanian-Zad, S. (2011). Nonfermented ice cream as a carrier for Lactobacillus acidophilus and Lactobacillus rhamnosus. International Journal of Food Science and Technology, 46(1), 84-92. doi:10.1111/j.1365-2621.2010.02453.x.

[24] Tripathi, M. K., \& Giri, S. K. (2014). Probiotic functional foods: Survival of probiotics during processing and storage. Journal of Functional Foods, 9(1), 225-241. doi:10.1016/j.jff.2014.04.030.

[25] Rathore, S., Desai, P. M., Liew, C. V., Chan, L. W., \& Heng, P. W. S. (2013). Microencapsulation of microbial cells. Journal of Food Engineering, 116(2), 369-381. doi:10.1016/j.jfoodeng.2012.12.022. 
[26] Gasperini, L., Mano, J. F., \& Reis, R. L. (2014). Natural polymers for the microencapsulation of cells. Journal of the Royal Society Interface, 11(100). doi:10.1098/rsif.2014.0817.

[27] Chen, J., Wang, Q., Liu, C. M., \& Gong, J. (2017). Issues deserve attention in encapsulating probiotics: Critical review of existing literature. Critical Reviews in Food Science and Nutrition, 57(6), 1228-1238. doi:10.1080/10408398.2014.977991.

[28] Pato, U., Ayu, D. F., Riftyan, E., Restuhadi, F., Pawenang, W. T., Firdaus, R., Rahma, A., Surono, I. S., \& Jaswir, I. (2021). Physicochemical property of oil palm leaves and utilization of cellulose microfiber as probiotic encapsulant. Biodiversitas, 22(7), 2937-2944. doi:10.13057/biodiv/d220746.

[29] Books in Brief. (1997). Journal of AOAC INTERNATIONAL, 80(6), 127A-128A. doi:10.1093/jaoac/80.6.127a.

[30] Jung, S. J., Kim, S. H., \& Chung, I. M. (2015). Comparison of lignin, cellulose, and hemicellulose contents for biofuels utilization among 4 types of lignocellulosic crops. Biomass and Bioenergy, 83, 322-327. doi:10.1016/j.biombioe.2015.10.007.

[31] Yasim-Anuar, T. A. T., Ariffin, H., Norrrahim, M. N. F., \& Hassan, M. A. (2017). Factors affecting spinnability of oil palm mesocarp fiber cellulose solution for the production of microfiber. BioResources, 12(1), 715-734. doi:10.15376/biores.12.1.715734.

[32] Lestari, F. A., (2016). Production of cellulose nanofiber hydrogels from oil palm empty fruit bunches. Thesis. Bogor Agricultural University, Bogor, Indonesia.

[33] Fung, W. Y., Yuen, K. H., \& Liong, M. T. (2011). Agrowaste-based nanofibers as a probiotic encapsulant: Fabrication and characterization. Journal of Agricultural and Food Chemistry, 59(15), 8140-8147. doi:10.1021/jf2009342.

[34] Yasim-Anuar, T. A. T., Ariffin, H., \& Hassan, M. A. (2018). Characterization of cellulose nanofiber from oil palm mesocarp fiber produced by ultrasonication. IOP Conference Series: Materials Science and Engineering, 368(1). doi:10.1088/1757899X/368/1/012033.

[35] Pato, U., Ali, M., \& Parlindungan, A. K. (2005). Taurocholate deconjugation and cholesterol binding by indigenous dadih lactic acid bacteria. HAYATI Journal of Biosciences, 12(3), 103-107. doi:10.1016/S1978-3019(16)30334-5.

[36] Nuraida, L., S, S., Palupi, N. S., H, H., Bastomi, R. R., Priscilia, D., \& Nurjanah, S. (2012). Evaluation of probiotics properties of lactic acid bacteria isolated from breast milk and their potency as starter culture for yoghurt fermentation. International Journal of Food, Nutrition and Public Health, 5(1-2-3), 33-60. doi:10.47556/j.jifnph.5.1-2-3.2012.3.

[37] IBM SPSS Statistics 26 [Computer software]. Available online: https://www.ibm.com/support/pages/downloading-ibm-spssstatistics-26 (accessed on August 2021).

[38] Ridwansyah, M. Z., Nasution, T. C., Sunarti, \& Fauzi, A. M. Physico-chemical characteristics of oil palm starter. Jurnal Teknologi Industri Pertanian, 17(1), 1-6,

[39] Winarni, I., Komarayati, S., \& Bardant, T. B. (2016). Enzymatic Production of Bioethanol from Palm Oil Trunk Waste (Elaeis Guineensis) with the Addition of Surfactants. Jurnal Penelitian Hasil Hutan, 34(2), 127-135. doi:10.20886/jphh.2016.34.2.127135.

[40] Lamaming, J., Chai Chew, S., Hashim, R., Sulaiman, O., \& Sugimoto, T. (2017). Extraction of microcrystalline cellulose from oil palm trunk. Journal of the Japan Institute of Energy, 96(11), 513-518. doi:10.3775/jie.96.513.

[41] Tomimura, Y. (1992). Chemical characteristics and utilization of oil palm trunks. Jarq-Japan Agricultural Research Quarterly, 25(4), 283-288.

[42] Deli, N. A. (2017). Delignification of nonproductive palm trunk by organosolv process with formic acid. Industria: Jurnal Teknologi Dan Manajemen Agroindustri, 6(3), 113-118. doi:10.21776/ub.industria.2017.006.03.1.

[43] Lamaming, J., Chai Chew, S., Hashim, R., Sulaiman, O., \& Sugimoto, T. (2017). Extraction of Microcrystalline Cellulose from Oil Palm Trunk. Journal of the Japan Institute of Energy, 96(11), 513-518. doi:10.3775/jie.96.513.

[44] Gümüskaya, E., Usta, M., \& Kirci, H. (2003). The effects of various pulping conditions on crystalline structure of cellulose in cotton linters. Polymer Degradation and Stability, 81(3), 559-564. doi:10.1016/S0141-3910(03)00157-5.

[45] Chen, L., Wang, Q., Hirth, K., Baez, C., Agarwal, U. P., \& Zhu, J. Y. (2015). Tailoring the yield and characteristics of wood cellulose nanocrystals (CNC) using concentrated acid hydrolysis. Cellulose, 22(3), 1753-1762. doi:10.1007/s10570-015-06151 .

[46] Sun, R. C., Tomkinson, J., Ma, P. L., \& Liang, S. F. (2000). Comparative study of hemicelluloses from rice straw by alkali and hydrogen peroxide treatments. Carbohydrate Polymers, 42(2), 111-122. doi:10.1016/S0144-8617(99)00136-8.

[47] Sianturi, A.H., (2018). Analysis of total hardness and alkalinity in clean water drilling wells with the Titrim method in Sucofindo, Co. Thesis. Universitas Sumatera Utara, Nort Sumatera, Indonesia. 
[48] Bilang, M., Tahir, M., \& Haedar, D. (2018). Studying the encapsulation viability of probiotic cells (Lactobacillus plantarum and Streptococcus thermophilus) in ice cream. Canrea Journal: Food Technology, Nutritions, and Culinary Journal, 41-52. doi:10.20956/canrea.v1i1.21.

[49] Hossain, M. N., Ranadheera, C. S., Fang, Z., \& Ajlouni, S. (2021). Impact of encapsulating probiotics with cocoa powder on the viability of probiotics during chocolate processing, storage, and in vitro gastrointestinal digestion. Journal of Food Science, 86(5), 1629-1641. doi:10.1111/1750-3841.15695.

[50] Massounga Bora, A. F., Li, X., Zhu, Y., \& Du, L. (2019). Improved viability of microencapsulated probiotics in a freeze-dried banana powder during storage and under simulated gastrointestinal tract. probiotics and antimicrobial proteins, 11(4), 13301339. doi:10.1007/s12602-018-9464-1.

[51] Arepally, D., Reddy, R. S., \& Goswami, T. K. (2020). Studies on survivability, storage stability of encapsulated spray dried probiotic powder. Current Research in Food Science, 3, 235-242. doi:10.1016/j.crfs.2020.09.001.

[52] Hill, C., Guarner, F., Reid, G., Gibson, G. R., Merenstein, D. J., Pot, B., Morelli, L., Canani, R. B., Flint, H. J., Salminen, S., Calder, P. C., \& Sanders, M. E. (2014). Expert consensus document: The international scientific association for probiotics and prebiotics consensus statement on the scope and appropriate use of the term probiotic. Nature Reviews Gastroenterology and Hepatology, 11(8), 506-514. doi:10.1038/nrgastro.2014.66.

[53] Rizqiati, H., Nurhidayat, N., \& Nurwitri, C. C. Characteristics of probiotic microcapsules of Lactobacillus plantarum encapsulated with skim milk and arabic gums. J. Indon. Trop. Anim. Agric, 34(2), 139-144.

[54] Ngov, Sina; Sukboonyasatit, Duljira; Phaseepol, T. (2014). Enhancement of probiotic survival in low pH and bile salt condition using alginate-hi-maize starch encapsulation. KKU Res. J., 19, 141-147.

[55] Afzaal, M., Saeed, F., Arshad, M. U., Nadeem, M. T., Saeed, M., \& Tufail, T. (2019). The effect of encapsulation on the stability of probiotic bacteria in ice cream and simulated gastrointestinal conditions. Probiotics and Antimicrobial Proteins, 11(4), 13481354. doi:10.1007/s12602-018-9485-9.

[56] Sohail, A., Turner, M. S., Coombes, A., Bostrom, T., \& Bhandari, B. (2011). Survivability of probiotics encapsulated in alginate gel microbeads using a novel impinging aerosols method. International Journal of Food Microbiology, 145(1), $162-168$. doi:10.1016/j.ijfoodmicro.2010.12.007.

[57] De Smet, I., Van Hoorde, L., Vande Woestyne, M., Christiaens, H., \& Verstraete, W. (1995). Significance of bile salt hydrolytic activities of lactobacilli. Journal of Applied Bacteriology, 79(3), 292-301. doi:10.1111/j.1365-2672.1995.tb03140.x.

[58] Dianawati, D., Mishra, V., \& Shah, N. P. (2016). Viability, acid and bile tolerance of spray dried probiotic bacteria and some commercial probiotic supplement products kept at room temperature. Journal of Food Science, 81(6), M1472-M1479. doi:10.1111/1750-3841.13313.

[59] Dikit, P., H-Kittikun, A., \& Maneerat, S. (2015). Survival of encapsulated potentially probiotic Lactobacillus plantarum D6SM3 with bioemulsifier derived from spent yeast in simulated gastrointestinal conditions. Songklanakarin Journal of Science and Technology, 37(4), 425-432.

[60] Ding, W. K., \& Shah, N. P. (2007). Acid, bile, and heat tolerance of free and microencapsulated probiotic bacteria. Journal of Food Science, 72(9), 446-450. doi:10.1111/j.1750-3841.2007.00565.x.

[61] Usman, \& Hosono, A. (1999). Viability of Lactobacillus gasseri and its cholesterol-binding and antimutagenic activities during subsequent refrigerated storage in nonfermented milk. Journal of Dairy Science, 82(12), 2536-2542. doi:10.3168/jds.S00220302(99)75507-4.

[62] Praepanitchai, O. A., Noomhorm, A., Anal, A. K., \& Potes, M. E. (2019). Survival and behavior of encapsulated probiotics (Lactobacillus plantarum) in calcium-alginate-soy protein isolate-based hydrogel beads in different processing conditions ( $\mathrm{pH}$ and temperature) and in pasteurized mango juice. BioMed Research International, 2019(3). doi:10.1155/2019/9768152. 